Brit. F. vener. Dis. (1972) 48, 187

\title{
Gonococcal hepatitis (Fitz-Hugh Curtis syndrome) in a male patient
}

\author{
T. I. FRANCIS* AND A. O. OSOBAt \\ University College Hospital, Ibadan, Nigeria
}

Classical gonococcal infection involves the genitourinary tract. Extragenital localization or dissemination may arise from gonococcal septicaemia, causing arthritis, or cutaneous and other lesions including perihepatitis (Kaye, 1967; King, 1964; Kimball and Knee, 1970) or it may arise from abnormal sexual practices resulting in parotitis (Diefenbach, 1953), pharyngitis (Fiumara, Wise, and Many, 1967), or proctitis (Harkness, 1948; Catterall, 1962). Liver involvement by gonococcal infection (perihepatitis) is a rare complication; it was first described by Stajano (1920) and is sometimes known eponymously as the Fitz-Hugh and Curtis Syndrome (Fitz-Hugh, 1934，1936; Curtis，1930). Previous descriptions have been of cases in females and the first male case was reported by Kimball and Knee (1970).

This paper reports another case in a male Nigerian with the object of alerting physicians to this rare complication.

\section{Case Report}

A 25-year-old brick-layer was admitted to the University College Hospital (UCH), Ibadan, in January, 1971, with one month's history of right upper abdominal pain, jaundice, fever, and dysuria, and a painful swelling of the left knee, both ankles, and right wrist for 6 days. He admitted to sexual intercourse with a prostitute a month before the onset of his illness; 5 days after this sexual exposure he had noticed a purulent urethral discharge accompanied by dysuria. He took herbal infusions for a few days and had noticed a decrease in the urethral discharge, but the dysuria persisted up till his admission to hospital.

\section{Examination}

He looked ill, febrile (temperature $102^{\circ} \mathrm{F}$.), and mildly jaundiced. Abnormal signs were limited to the abdomen, locomotor system, and penis. The liver was palpable $3 \mathrm{~cm}$. below the right costal margin and was very tender. The urethral meatus was reddened and a purulent urethral discharge could be expressed. Warm tender

Received for publication June 7, 1971

*Consultant Physician and Senior Lecturer in Medicine

tConsultant in Venereal Diseases and Lecturer in Microbiology effusions were present in the left knee, both ankles, and right wrist.

\section{Diagnosis}

Gonococcal septicaemia complicated by polyarthritis and hepatitis.

\section{Investigations}

Packed cell volume (PCV) 31 per cent. white cell count (W.B.C.) $10,400 /$ c.mm. with 67 per cent. neutrophil polymorphs. The haemoglobin genotype was AA. Red cells were not glucose-6-phosphate dehydrogenase deficient, the erythrocyte sedimentation rate was $103 \mathrm{~mm} . / 1 \mathrm{st}$ hour (Westergren). A midstream urine specimen showed 5 to 8 white cells per high-power field and culture yielded no growth. Blood cultures were sterile.

Urethral specimens were collected and a Gram-stained smear showed both intracellular and extracellular Gramnegative diplococci. Candida albicans was not seen and a wet smear for Trichomonas vaginalis was negative. Further specimens were plated at the bedside on brain-heart infusion agar in which Colistin, Nystatin, and Vancomycin had been incorporated. After $\mathbf{4 8} \mathrm{hrs}$ ' incubation, gonococci were isolated and identified by a positive oxidase test and by fermentation reactions. The sensitivity of the isolated strain was tested by the Oxoid multodisk method and was found to be sensitive to penicillin ( 1.5 units), tetracycline $(10 \mu \mathrm{g}$.$) , and streptomycin (10 \mu \mathrm{g}$.).

A two-glass urine test showed threads in the first glass only, indicating an anterior urethritis. Total bilirubin was $3.1 \mathrm{mg} . / 100 \mathrm{ml}$., conjugated bilirubin $2.5 \mathrm{mg} . / 100 \mathrm{ml}$., S.G.O.T. 24 caband units $/ \mathrm{ml}$., and S.G.P.T. 30 caband units $/ \mathrm{ml}$. Serum proteins and electrolytes and urea were normal. The VDRL was nonreactive and the antistreptolysin titre was also normal.

$\mathrm{He}$ was treated with analgesics and with crystalline penicillin 8 million units per day, given in divided doses from the 4th hospital day for 16 days. The fever settled within 3 days of starting specific therapy, the liver pain subsided, and the jaundice had gone by the 8 th day. The polyarthritis had resolved by the time he was discharged from hospital 23 days after admission.

\section{Discussion}

Genito-urinary gonococcal infection is a very frequent disease in Ibadan (Osoba, 1972), but no case of hepatitis or perihepatitis in association with 
gonorrhoea has so far been seen, which further emphasizes the rarity of this complication. Curtis (1930), Fitz-Hugh (1934, 1936), and Vickers and Maloney (1964) described this syndrome in females and it was suggested that the infection ascended by way of the Fallopian tube and paracolic gutters to the subphrenic spaces. The first case of gonococcal perihepatitis in a male was that reported by Kimball and Knee (1970). The differential diagnosis in their case included acute cholecystitis; there was biochemical evidence of hepatocellular damage, but the liver histology was normal, and a culture of tissue obtained at biopsy grew $N$. gonorrhoeae. The organism was not recovered in the cases reported by Vickers and Maloney (1964).

Gonococcal arthritis, which was said to complicate 1 to 5 per cent. of cases of gonococcal urethritis before the sulphonamide era (Balboni, 1960), results from blood-borne dissemination of gonococci. As in this patient, the polyarthritis responds dramatically to penicillin.

The presence of gonococcal arthritis and hepatitis would suggest gonococcal septicaemia as the source of these complications. Gonococci can seldom be isolated from the joint fluid in early cases with polyarthritis. The spread of the organisms through the retroperitoneal lymphatics causing perihepatitis has been suggested as an alternative route of liver involvement.

Because of the few reported cases of liver involvement by gonococcal infection, treatment regimes are not standardized. The cases so far treated show that the response to penicillin is good, provided the gonococcus is penicillin sensitive, and that treatment is given for at least 10 days.

\section{Summary}

Gonococcal hepatitis is a very rare complication of genito-urinary gonococcal infection in men. Only one previous report is available in the literature. Another case, in a male Nigerian who also had polyarthritis, is presented. The purpose of this report is to alert physicians to this complication during a period of rapid increase in the incidence of venereal disease.

\section{References}

Balboni, V. G. (1960) In 'Arthritis and Allied Conditions', ed. J. L. Hollander, 6th ed., p. 927. Lea and Febiger, Philadelphia

Catterall, R. D. (1962) Proc. roy. Soc. Med., 55, 871

Curtis, A. H. (1930) f. Amer. med. Ass., 94, 1221

DiefENBACH, W. C. L. (1953) Oral Surg., 6, 974

Fitz-Hugh, T. J. (1934) f. Amer. med. Ass., 102, 2094

- (1936) Rev. Gastroenterol., 3, 125

Fuimara, M. J., Wise, H. M., and MANY, M. (1967) New Engl. F. Med., 276, 1248

HARkness, A. H. (1948) Proc. roy. Soc. Med., 41, 476

KAYE, D. (1967) 'Gonococcal disease' in 'Cecil Loeb Textbook of Medicine', ed. P. B. Beeson and W. McDermott, 12th ed., pp. 186-190. Saunders, Philadelphia

KIMBALI, M. W., and KNEE, S. (1970) New Engl. F. Med., 282, 1082

KING, A. J. (1964) 'Recent Advances in Venereology', pp. 231-234. Churchill, London

Osoba, A. O. (1972) Brit. F. vener. Dis., 48, 116

Stajano, C. (1920) Sem. med. (B. Aires), 27, 243

VICKERS, F. N., and MALONEY, P. J. (1964) Arch. intern. Med., 114, 120

\section{Hépatite gonococcique (Syndrôme de Fitz-Hugh et Curtis) chez un homme}

\section{SOMMAIRE}

L'hépatite gonococcique est une complication très rare de l'atteinte gonococcique génito-urinaire chez l'homme. Jusqu'ici, on ne dispose que d'un cas rapporté dans la littérature. On présente un deuxième cas chez un Nigérien atteint aussi de polyarthrite. Le but de cet article est d'alerter les médecins à l'égard de cette complication à un moment où l'on se trouve en période d'augmentation rapide de l'incidence des maladies vénériennes. 